\title{
NILAI TOLERANSI DALAM CERPEN-CERPEN TERBITAN KORAN REPUBLIKA DARING DAN RELEVANSINYA SEBAGAI MATERI AJAR SASTRA DI SMA
}

\author{
Elvira Rahayu, Imam Muhtarom, Sahlan Mujtaba \\ Universitas Singaperbangsa Karawang \\ Email: elvirarahayu5@gmail.com, arjotaruno@gmail.com, \\ bahuysahlan@gmail.com
}

\begin{abstract}
Abstrak: Cerpen adalah prosa fiksi yang dibangun melalui unsur instrinsik dan ekstrinsik. Penelitian ini bertujuan untuk (1) mendeskripsikan unsur intrinsik, (2) mendeskripsikan nilai toleransi dan (3) membuat relevansi materi ajar sastra. Sumber data penelitian ini adalah 104 judul cerpen yang terbit di koran Republika Daring 2019. Yang menjadi sampel adalah 10 cerpen. Metode yang digunakan adalah deskriptif kualitatif dengan pendekatan analisis isi. Hasil penelitian ini adalah sebagai berikut (1) unsur intrinsik: alurnya mayoritas campuran, tokohnya meliputi protagonis dan antagonis, latarnya meliputi latar tempat, latar waktu dan latar sosial budaya, amanatnya ajakan berperilaku baik, bahasanya populer, sudut pandang didominasi orang ketiga, dan mayoritas bertema pendidikan; (2) nilai toleransi antara lain: sikap saling menghargai perbedaan pendapat, perbedaan keyakinan, agama, kepercayaan, tidak memaksakan kehendak dan menghargai keputusan orang lain; (3) relevan sebagai materi ajar sastra di SMA.
\end{abstract}

Kata Kunci: cerpen, Republika, unsur intrinsik, nilai toleransi.

\section{VALUE OF TOLERANCE IN THE SHORT STORY OF “REPUBLIKA" ONLINE NEWSPAPERS AND ITS RELEVANCE AS LITERATURE TEACHING MATERIAL IN SENIOR HIGH SCHOOL}

\begin{abstract}
Short stories are prose fiction which is built through intrinsic and extrinsic elements. This writing aims to (1) describe the intrinsic element, (2) describe the value of tolerance and (3) make the relevance of literary teaching materials. The data sources of this research were 104 short stories published in the 2019 Republika Daring newspaper. The samples were 10 short stories. The method used is descriptive qualitative with a content analysis approach. The results of this study are as follows: (1) intrinsic elements: the plot is mostly mixed, the characters include the protagonist and the antagonist, the setting includes place, time and socio-cultural background, mandate of an invitation to behave well, the language is popular, the point of view is dominated by a third person, and the majority on the theme of education; (2) the value of tolerance, among others: mutual respect for differences of opinion, differences in belief, religion, belief, not imposing one's will and respecting the decisions of others; (3) relevant as literature teaching material in senior high school.
\end{abstract}

Keywords: short story, Republika, elements intrinsic, tolerance value.

\section{PENDAHULUAN}

Di negara Indonesia akhir-akhir ini banyak terjadi kasus intoleransi.
Fenomena yang terjadi berupa penyerangan terhadap tempat ibadah umat muslim, gereja, vihara, dan lain-

BASASTRA Jurnal Bahasa, Sastra,dan Pengajarannya

Volume 9 Nomor 1, April 2021, P-ISSN 2302-6405, E-ISSN 2714-9765 
lain (Muzakir, 2020). Selain itu beberapa konflik etnis Tionghoa dengan etnis Pribumi, tragedi sampit yang dilakukan oleh suku Dayak melawan suku Madura (Intisari, 2020). Konflik perbedaan agama yang terjadi di Ambon, pelecehan yang dilakukan oleh seorang murid kepada guru, perundungan yang terjadi kepada siswa SMA dengan ras kulit hitam dan beberapa perdebatan yang berakibat perselisihan pendapat dalam suatu hal (Juliawanti, 2018). Beberapa kasus tersebut membuat generasi muda mengalami keterlambatan dalam perkembangan pendidikan karakter dalam segi nilai toleransi.

Terkait permasalahan di atas yang masih terjadi sampai saat ini, sehingga menunjukkan bahwa kasus intoleransi dapat membuat sikap seseorang menjadi negatif. Selain itu, membuat sudut pandang sebuah bangsa dinilai negatif. Karena sikap toleransi yang tertanam di dalam masyarakat mencerminkan pola kehidupannya. Toleransi diartikan sebagai harmoni dalam perbedaan, yang membuat perdamaian menjadi hal yang mungkin (Irwan, 2011). Seiring pernyataan tersebut, toleransi harus tumbuh dalam setiap perilaku masyarakat. Sehingga terbentuk kehidupan yang damai tanpa harus mendebatkan masalah perbedaan di setiap individu. Maka dari itu, toleransi secara luas, yaitu perilaku atau sikap manusia yang menghargai setiap tindakan, pendapat, kepercayaan yang dilakukan orang lain.
Sementara itu, dalam pendidikan khususnya pelajaran Bahasa Indonesia pendidik akan lebih efisien dalam memberikan penanaman nilai toleransi melalui materi ajar sastra. Kata sastra dalam khazanah Jawa kuno berasal dari bahasa Sansekerta. Hal ini berarti seperti mengarahkan, mengajar, atau memberi petunjuk. Hal ini berkaitan dengan pendapat yang dikemukakan Wellek \& Werren tentang fungsi sastra untuk pembaca (Emzir \& Rohman, 2016). Dapat dijelaskan beberapa fungsi sastra seperti (1) hiburan; (2) renungan; (3) bahan pelajaran; (4) media komunikasi simbolik; dan (5) pembuka paradigma berpikir. Oleh karena itu, seorang guru dengan mudah memberikan nilai-nilai kehidupan tentang pendidikan karakter. Hal ini juga sesuai dengan kompetensi dasar 3.8, 3.9, 4.8 dan 4.9 dalam kurikulum 2013 khususnya pada materi cerpen bagian nilai toleransi. Cerpen sebagai genre salah satu karya sastra yang digunakan untuk sarana pembelajaran terhadap peserta didik. Cerpen atau cerita pendek adalah tulisan yang menggambarkan tentang kehidupan manusia di suatu tempat dan dalam kurun waktu tertentu (Heri, 2019). Dalam ragam jenis karya sastra, cerpen termasuk ke dalam jenis prosa yang cocok untuk dipelajari oleh peserta didik di sekolah. Sebab, cerpen memiliki unsur pembangun, yaitu unsur intrinsik dan ekstrinsik. Unsur di dalam cerpen meliputi: tema, tokoh, penokohan, setting, alur, amanat dan 
gaya bahasa. Melalui unsur tersebut, peserta didik dapat dengan mudah memahami nilai toleransi yang ingin disampaikan oleh pendidik.

Koran Republika Daring merupakan tempat pemilihan cerpen yang akan dijadikan subjek penulisan. Hal yang menjadi pertimbangan seperti koran Repubika Daring ini sudah berdiri sejak 1993 dan telah memiliki akses layanan koran sejak 1995. Selain itu, merupakan portal berita yang menyajikan informasi berupa teks, audio dan video. Saat ini Republika Daring hadir dengan fitur campuran dari berbagai macam genre. Salah satunya kolom sastra yang dapat menjadi wadah bagi komunitas yang gemar mengekspresikan diri melalui karya sastra cerpen. Lebih dari itu, memberikan kesempatan kepada siapa pun yang ingin serius menggeluti dunia tulis-menulis sebuah karya sastra. Karya sastra yang diterbitkan seperti puisi, cerpen, dan syair. Penulis telah membaca 104 judul cerpen yang diterbitkan Koran Republika Daring pada 2019 secara bertahap. Namun, penulis memutuskan untuk memilih subjek penulisan berupa cerpen pilihan. Sehingga memutuskan untuk memilih 10 judul cerpen saja. Hal ini dikarenakan memiliki kesamaan topik dalam membahas nilai toleransi di kehidupan masyarakat. Seperti (1) Hati Sang Pemilik Kucing oleh Irwan Kelana, (2) Lelaki Pengurus Orang Mati oleh Risen Dhawuh Abdullah, (3) Kalam Ilahi di Balik Jeruji Besi oleh
Julia Hartini, (4) Pelangi di Kota Changhua oleh Eti Nur Halimah, (5) Setagaya Aku Ingin Pulang oleh Agung Zakaria, (6) Lebaran di Perantauan oleh Eti Nurhalimah, (7) Riwayat Petani Tembakau oleh Alim Musthafa, (8) Bukan Untukmu Kujemput Rindu oleh Irwan Kelana, (9) Shalawat Cinta dari Venesia oleh Irwan Kelana dan (10) Mimpi dan Takdir oleh Raihan Sabathani.

Berikut beberapa penelitian terdahulu yang dijadikan sumber referensi dalam penelitian ini. Penelitian yang dilakukan oleh Kahfi (2018) yang menyatakan bahwa hasil penelitian memandang nilai toleransi, seperti kultural, suku, jenis kelamin, agama dan sebagainya berdasarkan UUD 1945. Penelitian yang dilakukan oleh Utomo, Hasanah \& Maryaeni (2020). Hasil penelitian meliputi (1) sikap sopan santun dan (2) memahami identitas sosial. Penelitian yang dilakukan oleh Rantesalu \& Iswanto (2020). Adapun nilai toleransi yang terkandung berupa nilai keberterimaan dan kesepahaman. Penelitian yang dilakukan oleh Tantri (2017) yang menyatakan terdapat 18 nilai karakter yaitu religius, jujur, toleransi, disiplin, kerja keras, kreatif, mandiri, demokratis, rasa ingin tahu, semangat kebangsaan, cinta tanah air, menghargai prestasi, bersahabat, cinta damai, gemar membaca, peduli lingkungan, sosial dan tanggung jawab. Penelitian yang dilakukan oleh Sukma, Andayani \& Mujiyanto (2019). 
Simpulan dalam penulisan, berupa (1) aspek latar sosial, (2) latar belakang sosial, (3) tanggapan pembaca, (4) nilai toleransi, dan (5) novel kambing dan hujan sebagai bahan materi ajar.

Sedangkan beberapa penelitian lainnya dijadikan sebagai alternatif sumber referensi dalam penelitian ini. Penelitian yang dilakukan oleh Ilham \& Wijati (2018) yang jenis penelitiannya termasuk ke dalam penulisan kualitatif. Suryadi, Azis \& Utama (2018) yang data penelitiannya berupa satuan lingual berupa kata, frasa, klausa dan kalimat yang mengandung unsur nilai sosial. Penelitian yang dilakukan oleh Wahyudi (2019) menggunakan metode riset kualitatif dengan pendekatan fenomenologi sebagai pisau analisisnya. Penelitian yang dilakukan oleh Widiyanto (2017) yang dalam penelitiannya digunakan kajian literatur dengan mencari dan mengumpulkan data yang sesuai. Penelitian yang dilakukan Anderson \& Putri (2017), prosedur dalam mengumpulkan data menggunakan teknik observasi, wawancara dan dokumentasi.

Agar semakin menguatkan sumber referensi yang relevan, maka berikut hasil penelitian terdahulu. Penelitian yang dilakukan oleh Suhardi \& Thahirah (2018) menyatakan nilai pendidikan karakter yang terkadung berupa (1) religius, (2) kejujuran, (3) toleransi, (4) disiplin, (5) kerja keras, (6) mandiri, (7) komunikatif, (8) cinta damai dan (9) peduli sosial. Penelitian yang dilakukan oleh Vardani (2018) prosedur penelitian yang dilakukan dengan tahap perencanaan, pelaksanaan dan penyelesaian. Penelitian yang dilakukan oleh Suyadi \& Nuryatin (2017), pendekatan yang digunakan adalah pendekatan objektif dan pendekatan pragmatik. Penelitian yang dilakukan oleh Nurjaya, Supendi \& Firdaus (2019), teknik pengumpulan data yang digunakan melalui observasi, tes, angket dan dokumentasi. Penelitian yang dilakukan oleh Maryanti, Sujiana \& Wikanengsih (2018) yang menggunakan metode deskriptif kualitatif. Penelitian yang dilakukan oleh Limbong (2016) yang dilakukan secara deskriptif kualitatif. Penelitian yang dilakukan oleh Subekti, Sutarjo, \& Wardana (2016) yang menganalisis unsur intrinsik berupa tema, tokoh, latar, sudut pandang dan moral. Penelitian yang dilakukan oleh Sapdiani, Maesaroh, Pirmansyah \& Firmansyah (2018) yang mengombinasikan unsur-unsur intrinsik dalam cerpen. Penelitian yang dilakukan oleh Juanda (2018) yang menggunakan adalah teknik analisis isi. Penelitian yang dilakukan oleh Anggraini (2020) mengkaji unsur intrinsik berupa plot, setting, sudut pandang, tema, amanah, gaya bahasa, karakter, dan lain-lain.

Untuk rumusan masalah dalam penelitian ini adalah bagaimana (1) unsur intrinsik; (2) nilai toleransi yang terkandung; dan (3) relevansi sebagai 
materi ajar sastra yang sesuai. Maka tujuan dari penulisan ini untuk mendeskripsikan (1) unsur intrinsik, (2) nilai toleransi, dan (3) relevansi sebagai materi ajar sastra. Teori yang digunakan adalah prosa fiksi Nurgiyantoro. Sedangkan metode yang digunakan adalah content dan descriptive analysis. Sementara untuk pembaharuan dari penelitian terdahulu atau sebelumnya berupa subjek yang dipilih. Pada penelitian ini subjek berasal dari Republika Daring 2019. Maka ditentukan 10 cerpen dari 104 cerpen yang telah dibaca. Hal ini dikarenakan memiliki nilai kesamaan toleransi dan menarik untuk dibahas sebagai materi ajar sastra. Dengan harapan penelitian ini sebagai sumber referensi untuk pendidik dalam menentukan materi ajar sastra, khususnya di SMA. Sehingga dari unsur pembangun, nilai toleransi, dapat direlevansikan sebagai materi ajar yang bermanfaat untuk pendidik. Selain itu, peserta didik dapat menerapkannya dalam kehidupan sehari-hari.

\section{METODE}

Metode penelitian ini menggunakan metode kualitatif deskriptif. Metode penelitian kualitatif deskriptif disebut juga metode penelitian naturalistik. Hal ini karena dilakukan pada kondisi yang alamiah (natural setting) (Sugiyono, 2017). Maka dari hal ini dirasa sesuai dengan penelitian yang akan dilakukan. Objek dalam penelitian ini adalah nilai pendidikan karakter toleransi. Sedangkan subjek yang dipilih adalah cerpen pilihan koran Republika Daring 2019. Namun, hanya memilih 10 dari 104 judul cerpen yang terbit pada tahun 2019. Hal ini dikarenakan memiliki nilai kesamaan toleransi yang menarik untuk dibahas sebagai materi ajar sastra. Dengan harapan penelitian ini sebagai sumber referensi untuk pendidik dalam menentukan materi ajar sastra, khususnya di SMA.

Data dalam penelitian ini berupa nilai pendidikan karakter toleransi dalam 10 cerpen pilihan dari koran Republika Daring 2019 dan hasil wawancara melalui whatsapp. Selain itu, sumber data yang dikumpulkan oleh penulis seperti cerpen pilihan sebagai sumber data primer dan hasil wawancara melalui whatsapp, sedangkan seperti ipusnas, Kamus Besar Bahasa Indonesia (KBBI), jurnal ilmiah, skripsi dan buku-buku teori digunakan untuk bahan pustaka penelitian dan sebagai sumber data sekunder. Dalam penelitian ini, peneliti menjadi instrumen dalam mengamati dan menganalisis cerpen pilihan. Selain itu, peneliti juga melibatkan partisipasi atau narasumber yang bersedia di wawancarai melalui whatsapp. Dengan menggunakan alat-alat tulis untuk mencatat dan memberikan tanda pada saat proses analisis cerpen.

Teknik pengumpulan data dilakukan dari sumber data primer dan sekunder yang ditentukan. Sumber data primer seperti koran Republika Daring 
dan wawancara daring. Sedangkan sumber data sekunder seperti hasil penelitian jurnal ilmiah, skripsi, buku teori, buku sastra, ipusnas, dan buku tentang toleransi. Sementara itu, teknik pengumpulan data yang digunakan peneliti adalah teknik triangulasi berupa: (1) dokumentasi, (2) baca dan catat dan (3) wawancara. Teknik analisis data menggunakan metode content dan descriptive analiyisis. Sebagai tahap awal akan menganalisis satu per satu cerpen yang terdapat di Koran Republika Daring 2019. Selanjutnya menganalisis unsur pembangun yang terdapat dalam cerpen. Tahap akhir menentukan pendidikan karakter nilai toleransi yang terdapat pada cerpen. Sehingga dapat dijadikan sebagai relevansi materi ajar sastra di SMA. Berikut adalah kerangka berpikir yang tergambar pada Gambar 1. di bawah ini.
Nilai Toleransi dalam Cerpen Koran Republika Daring 2019 sebagai Relevansi Bahan Ajar Sastra di SMA

Membaca Cerpen-Cerpen di Koran Republika Daring Tahun 2019

(1) Membaca, (2) Menyimak dan (3) Mencatat.

Unsur Intrinsik

Dipilih 10 Cerpen Pilihan dari 104 Cerpen yang Dibaca

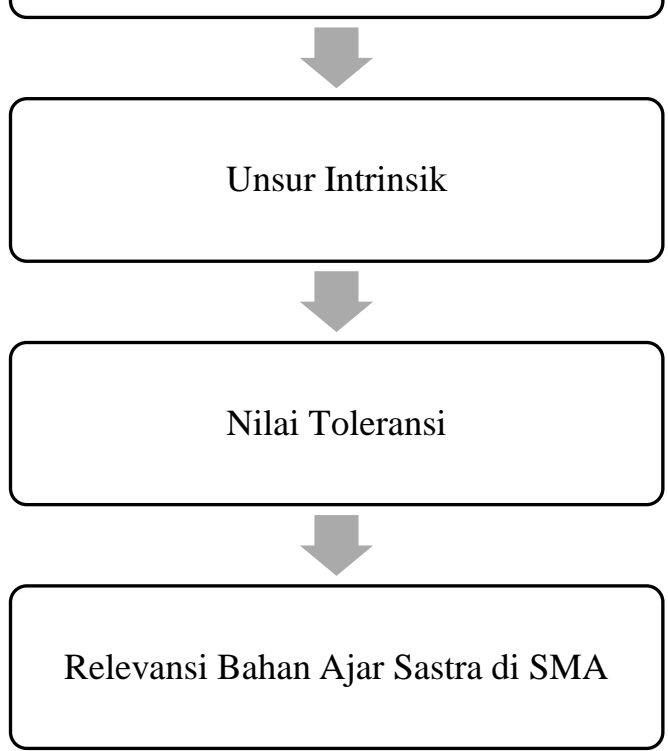

Gambar 1. Kerangka Berpikir

Penulisan

\section{HASIL DAN PEMBAHASAN}

Hasil pada penelitian ini dibuat dalam bentuk tabel. Selain itu hasil akhir membuat handout sebagai bahan ajar sastra yang sesuai dengan penulisan saat ini. Hal ini bertujuan agar pembaca dapat dengan mudah 
memahami 10 cerpen yang dijadikan subyek dalam penulisan ini. Pembahasan di mulai dari menentukan unsur intrinsik, nilai toleransi dan relevansi materi ajar sastra. Untuk cerpen pertama yang berjudul Hati Sang Pemilik Kucing (Kelana, 2019) seperti pada Tabel 1 di bawah ini.

Tabel 1. Unsur Intrinsik dalam Cerpen Berjudul Hati Sang Pemilik Kucing

\begin{tabular}{|c|c|}
\hline Indikator & Keterangan \\
\hline Alur & $\begin{array}{l}\text { Plot atau alur merupakan bagian yang pasti ada dalam struktur cerpen. } \\
\text { Alur yang menonjol berupa alur campuran (maju dan mundur). }\end{array}$ \\
\hline
\end{tabular}

Tokoh dan Penokohan $\quad$ Berdasarkan teori Nurgiyantoro terdiri dari: (1) tokoh utama (Fadil yaitu tokoh seorang laki-laki yang selalu mengalami kegagalan dalam kisah cintanya), (2) tokoh tambahan (a. Aisyah adalah seorang perempuan cantik dan baik hati, b. Qurata A'iyun tokoh perempuan solihah, pintar, baik, dan taat agama, c. Adian adalah seorang laki-laki yang memiliki niat baik terhadap Fadil yaitu mencarikan jodoh, d. Nadira adalah perempuan yang memiliki perawakan tinggi, putih, cantik yang sampai saat ini masih belum memiliki seorang pujaan hati, e. Kiai Makrum adalah seorang pimpinan pondok pesantren yang secara tidak sengaja bertemu dengan dokter Fadil di MAsjid, f. Nurul Izah adalah gadis yang baik hati, cantik, pembaca qari yang secara tidak sengaja bertemu dengan dokter Fadil di jalan saat dokter Fadil akan berangkat ke masjid untuk salat Zuhur dan g. Ibu Fadil tokoh ini tidak hadir secara langsung di dalam cerita. Namun diceritakan secara langsung oleh tokoh yang bernama Fadil kepada Kiai Makrum). Tokoh berdasarkan fungsi, yaitu protagonis dan antagonis. Biasanya, tokoh protagonis adalah yang menjadi tokoh utama dalam sebuah cerita. Selain tokoh protagonis, juga terdapat (1. Nurul Izah, 2. Ibu Fadil dan 3. Kiai Makrum). Sedangkan tokoh antagonis adalah yang sering muncul dalam cerita. Selain itu biasanya yang menyebabkan sebuah awal mula konflik adalah Nadira. Tokoh berdasarkan perwatakan, yaitu tokoh bulat adalah Fadil, tokoh sederhana adalah Ibu Fadil.

Latar Latar adalah tempat, waktu, suasana dan beberapa petunjuk saat terjadinya cerita berlangsung. Berdasarkan penjelasan dari Nurgiyantoro membagi latar menjadi tiga, yaitu tempat, waktu dan sosial budaya.

1. Latar tempat menunjukan ada 13 yang terdapat dalam cerita ini seperti di Desa Cianjur Jawa Barat, IPB, SDN Cianjur, Masjid AlAzhar Kebayoran Baru Jakarta, Universitas Al-Azhar Jakarta, Banjarmasin, McDonald's dekat UIN Ciputat, Pondok Cabe Depok, Serambi Depan, Lembaga Pengembangan Tilawatil Quran Cianjur, Gubuk Sederhana di pinggir Masjid dan Cianjur.

2. Latar waktu menunjukan ada 13 yang terdapat dalam cerita ini, seperti ramadan tahun ini, sejak SMA, dua tahun setelah lulus kuliah, minggu lalu, sejak kuliah sampai saat ini, tahun berikutnya, butuh waktu tiga tahun, sabtu sore, suatu pagi menjelang siang, hari ini ulang tahun saya, azan zuhur dan tiga hari kemudian.

3. Latar sosial budaya yang sangat melekat adalah ada dua peristiwa, yakni pertama saat peristiwa tokoh Fadil lama tidak memberikan kepastian kepada Aisha. 


\begin{tabular}{ll}
\hline Amanat & Amanat yang terkandung, yakni sebagai manusia harus selalu sabar \\
dan berprasangka baik terhadap orang lain. Selain itu jangan pernah \\
memiliki perasaan dendam terhadap orang yang sudah menyakiti, \\
harus selalu menolong kepada sesama tanpa mengharapkan pamrih \\
dan yang dapat menghargai pendapat orang lain. \\
\hline Bahasa & Gaya bahasa digunakan sangat baik, mudah dimengerti. Karena \\
& Senggunakan bahasa sehari-hari yakni bahasa Indonesia. \\
\hline Sudut Pandang pandang yang digunakan sudut pandang sudut pandang persona \\
pertama "Aku". Cerpen ini memiliki satu tokoh utama seorang Dokter \\
Hewan. Tokoh Fadil dalam cerpen ini dihadapkan dengan beberapa \\
konflik sebelum dia menemukan kebahagiaannya. \\
\hline Tema & merikut hasil yang didapat untuk bagian tema, terbagi menjadi tema \\
& keseluruhan isi cerita. Maka untuk tema mayor dalam cerita ini \\
mengenai tema tentang kesabaran. Tema minor adalah tema yang \\
hanya menjadi bagian kecil dari keseluruhan isi cerita. Tema minor \\
dalam cerita ini mengenai tema tentang sosial.
\end{tabular}

Nilai toleransi sangat terlihat jelas dalam cerpen ini. Ketika tokoh Fadil dihadapkan pada beberapa konflik yang dia terima. Maka nilai toleransi yang sangat menonjol dalam cerita adalah menghargai keputusan orang dan tidak memaksakan kehendak yang diyakini dan diinginkan oleh diri sendiri kepada orang lain .

Untuk cerpen kedua yang berjudul Lelaki Pengurus Orang Mati (Abdullah, 2019), seperti pada Tabel 2 di bawah ini.

Tabel 2. Unsur Intrinsik dalam Cerpen Berjudul Lelaki Pengurus Orang Mati

\begin{tabular}{ll}
\hline \multicolumn{1}{c}{ Indikator } & \multicolumn{1}{c}{ Keterangan } \\
\hline Alur & Alur yang digunakan dalam cerpen ini berupa alur maju dan mundur. \\
\hline Tokoh dan Penokohan & Berdasarkan teori Nurgiyantoro terdiri dari: (1) tokoh utama yaitu \\
& Kris, (2) tokoh tambahan yaitu (a. Fatimah, b. Orang Tua Fatimah, dan \\
& c. Muna). Sedangkan tokoh berdasarkan fungsi yaitu tokoh protagonis \\
& dan antagonis. Tokoh protagonis yaitu Kris, sedangkan tokoh \\
& antagonis yaitu Orang Tua Fatimah. Tokoh berdasarkan perwatakan, \\
& yaitu tokoh bulat adalah Kris dan tokoh sederhana adalah Orang Tua \\
& Fatimah. \\
\hline Latar & $\begin{array}{l}\text { Latar adalah tempat, waktu, suasana dan beberapa petunjuk saat } \\
\text { terjadinya cerita berlangsung. Berdasarkan penjelasan dari } \\
\text { Nurgiyantoro membagi latar menjadi tiga, yaitu tempat, waktu dan } \\
\text { sosial budaya: } \\
\text { 1. Latar tempat dalam cerpen ini terbagi menjadi di panti jompo dan } \\
\text { pinggir jalan raya. } \\
\text { 2. Latar waktu dalam cerpen ini terbagi dalam siang hari, pagi hari } \\
\text { dan dua tahun setelah pernikahan dengan Muna. } \\
\text { 3. Latar sosial budaya yang terlihat dari cerpen ini yakni peristiwa } \\
\text { saat keluarga Fatimah melihat seseorang dari kelas status sosialnya }\end{array}$ \\
$\begin{array}{l}\text { Amanat yang terkandung dalam cerpen adalah sebagai manusia jangan } \\
\text { pernah melihat atau menilai seseorang dari status sosial. Hal tersebut } \\
\text { bukanlah sikap yang terpuji. Selain itu harus menghargai apa pun } \\
\text { itu pekerjaan orang lain. }\end{array}$ \\
\hline Amanat
\end{tabular}

BASASTRA Jurnal Bahasa, Sastra, dan Pengajarannya

Volume 9 Nomor 1, April 2021, P-ISSN 2302-6405, E-ISSN 2714-9765 


\begin{tabular}{ll}
\hline Bahasa & Gaya bahasa yang digunakan dalam cerpen menggunakan bahasa \\
& Indonesia tidak baku (bahasa sehari-hari). Sehingga dalam \\
& penyampaian cerpen ini sangat mudah di pahami oleh pembaca. \\
& Dalam cerpen ini tidak terdapat kosa kata asing yang membuat cerpen. \\
& Sehingga dapat dengan mudah untuk dinikmati oleh pembaca \\
\hline Sudut Pandang & Sudut pandang yang dipakai menggunakan sudut pandang persona \\
& ketiga "Dia". Pada sudut pandang ini, narator adalah seseorang yang \\
& berada di luar cerita. Sehingga penyebutan tokoh dalam cerita \\
& menggunakan kata ganti. Sudut pandang ini kembali terbagi menjadi \\
& dua, yaitu "Dia" yang serba tahu dan "Dia" yang terbatas pengetahuan \\
& atau "Dia" sebagai pengamat. \\
\hline Tema & Berikut hasil yang didapat berupa tema mayor dan minor. Tema mayor \\
& dari cerpen tersebut mengenai kesabaran. Sedangkan tema minor \\
& dalam cerpen ini mengenai sosial.
\end{tabular}

Nilai toleransi yang disampaikan memiliki tujuan ingin membahagiakan Fatimah dan ingin menjadikan Fatimah sebagai istrinya. Namun, keadaan dan nasib tidak berpihak kepada Kris dan Fatimah. Hingga pada akhirnya, hasil dari sikap toleransi yang dilakukan oleh Kris, ia berpisah dengan Fatimah dan bertemu dengan seorang perempuan sederhana yang bernama Muna.

Untuk cerpen ketiga yang berjudul Kalam Ilahi di Balik Jeruji Besi (Hartini, 2019), seperti pada Tabel 3 di bawah ini.

Tabel 3. Unsur Intrinsik dalam Cerpen Berjudul Kalam Ilahi di Balik Jeruji Besi

\begin{tabular}{ll}
\hline \multicolumn{1}{c}{ Indikator } & \multicolumn{1}{c}{ Keterangan } \\
\hline Alur & Alur yang terjadi dalam cerpen menggunakan alur campuran Seperti \\
& dimulai dari tahap tengah, lalu ke tahap akhir kemudian ke tahap awal \\
& cerita.
\end{tabular}

BASASTRA Jurnal Bahasa, Sastra, dan Pengajarannya 


\begin{tabular}{ll}
\hline & $\begin{array}{l}\text { masa depan. Cerpen ini membuka pandangan penulis tentang sudut } \\
\text { pandang dalam menilai seseorang dan memperlakukan seseorang. }\end{array}$ \\
\hline Bahasa & Gaya bahasa yang digunakan dalam cerpen menggunakan bahasa \\
& sehari-hari yang mudah dipahami. Selain itu kosa kata yang digunakan \\
dapat dengan mudah dipahami dan dimengerti oleh pembaca. Tidak & terdapat penggunaan bahasa daerah dan bahasa asing dalam cerpen ini. \\
& Namun ada kata bahasa Indonesia yang tidak lazim seperti kata 'Hotel \\
& Prodeo' untuk nama lain sel tahanan. \\
\hline Sudut Pandang & Sudut pandang yang dipakai menggunakan sudut pandang persona \\
& ketiga "Dia". Pada sudut ini, narator adalah seseorang yang berada di \\
& luar cerita. Sehingga penyebutan tokoh-tokoh dalam ceritanya pun \\
& menggunakan kata ganti. \\
\hline Tema & Tema yang ditentukan terbagi menjadi tema mayor dan minor. Tema \\
& mayor dalam cerpen adalah sosial. Hal tersebut dilihat karena ada \\
& banyak sekali peristiwa yang terjadi melibatkan keluarga. Sedangkan \\
tema minor dalam cerpen adalah keagamaan.
\end{tabular}

Nilai toleransi yang terlihat saat Mas Dim memaklumi seorang Gih yang masih belum bisa membaca ayat suci Al-Quran. Mas Dim merangkul Gih untuk belajar bersama di pesantren itu. Melihat sikap Masi Dim yang sangat baik, Gih hatinya sangat tersentuh. Gih tidak menyangka bahwa dia akan dihargai meski belum bisa membaca ayat suci Al-Quran.

Untuk cerpen keempat yang berjudul Pelangi di Kota Changhua (Nurhalimah, 2019), seperti pada Tabel 4 di bawah ini.

Tabel 4. Unsur Intrinsik dalam Cerpen Berjudul Pelangi di Kota Changhua

\begin{tabular}{ll}
\hline \multicolumn{1}{c}{ Indikator } & \multicolumn{1}{c}{ Keterangan } \\
\hline Alur & Alur dalam cerpen tersebut menggunakan alur campuran. Sebab, di \\
& awal cerita sudah menyajikan cerita tentang ingatan di masa lalu. \\
& Selanjutnya berkembang dan di pertengahan dihadirkan kembali \\
& ingatan tentang masa lalu. Hingga pada akhirnya pembaca diajak \\
& untuk bernostalgia tentang masa lalu dalam cerpen. \\
\hline Tokoh dan Penokohan & Tokoh berdasarkan peran penting terbagi tokoh utama dan tambahan. \\
& Tokoh utama yaitu Amira, sedangkan tokoh tambahan Lilly, Nyonya \\
& Faang, Nanai, Pakde Narto, Gunadi dan Ibu. Tokoh berdasarkan fungsi \\
& terbagi tokoh protagonis dan antagonis. Tokoh protagonis adalah \\
& Nyonya Faang dan Amira, sedangkan tokoh antagonis adalah Nyonya \\
& Faang. Tokoh berdasarkan perwatakan dibagi menjadi tokoh bulat dan \\
& sederhana. Tokoh bulat adalah Amira, sedangkan tokoh sederhana \\
& adalah Nyonya Faang. \\
\hline Latar adalah tempat, waktu, suasana dan beberapa petunjuk saat \\
terjadinya cerita berlangsung. Berdasarkan penjelasan dari \\
Nurgiyantoro membagi latar menjadi tiga, yaitu tempat, waktu dan \\
sosial budaya: \\
1. Latar waktu terbagi di pagi, malam, siang, petang dan sepanjang \\
perjalanan di dalam kereta. \\
2. Latar tempat terjadi di jurusan Changhua, bel rumah nomor 69, \\
ruang makan, rumah sakit dan ruangan kerja.
\end{tabular}

BASASTRA Jurnal Bahasa, Sastra, dan Pengajarannya 


\begin{tabular}{ll}
\hline & $\begin{array}{c}\text { 3. Latar sosial budaya yang terdapat dalam cerpen adalah tentang } \\
\text { seorang perempuan yang bercita-cita menjadi seorang TKW di } \\
\text { luar negeri. Hal tersebut menjadi budaya untuk masyarakat. }\end{array}$ \\
\hline Amanat & $\begin{array}{l}\text { Amanat yang terkandung dalam cerpen yaitu sebagai manusia harus } \\
\text { tetap menghormati perbedaan dan saling menerima perbedaan yang } \\
\text { ada. Selain itu, sebagai manusia jangan pernah menilai seseorang dari } \\
\text { luarnya saja. Hal ini dikarenakan pada kodratnya manusia diciptakan } \\
\text { beserta hati dan perasaannya. }\end{array}$ \\
\hline Bahasa & $\begin{array}{l}\text { Gaya bahasa yang dipakai dalam cerpen menggunakan bahasa sehari- } \\
\text { hari yang mudah dipahami. Selain itu kosa kata yang digunakan sangat } \\
\text { mudah dipahami dan dimengerti oleh pembaca. }\end{array}$ \\
\hline Sudut Pandang & $\begin{array}{l}\text { Sudut pandang yang dipakai menggunakan sudut pandang persona } \\
\text { ketiga "Dia" Pada sudut ini, narator adalah seseorang yang berada di } \\
\text { luar cerita. Sehingga penyebutan tokoh-tokoh dalam ceritanya pun } \\
\text { menggunakan kata ganti. }\end{array}$ \\
\hline Tema & Tema terbagi menjadi tema mayor dan minor. Tema mayor dalam \\
& cerpen adalah sosial. Sedangkan tema minor dalam cerpen ini \\
mengenai sosial. Karena sepanjang ceritanya menceritakan tentang \\
kehidupan sosial yang biasa terjadi di lingkungan masyarakat. Namun \\
yang paling menonjol dalam alurnya yaitu kekeluargaan.
\end{tabular}

Nilai toleransi berupa sikap yang ditunjukan oleh Nyonya Faang setelah mengetahui musibah yang menimpa Amira. Sikap peduli dan menghargai kodrat manusia untuk saling menyayangi telah ditunjukkan oleh tokoh Nyonya Faang. Selain itu, Nyonya Faang memperlakukan Amira dengan baik tanpa membedakan antara majikan dan pembantu. Sikap toleransi yang terdapat dalam cerpen ini jarang dilakukan oleh manusia. Meski sebenarnya permasalahan yang seperti ini sering kali terjadi dalam kehidupan sehari-hari dalam masyarakat.

Untuk cerpen kelima yang berjudul Satagaya Aku Ingin Pulang (Zakaria, 2019), seperti pada Tabel 5 di bawah ini.

Tabel 5. Unsur Intrinsik dalam Cerpen Berjudul Satagaya Aku Ingin Pulang

\begin{tabular}{|c|c|}
\hline Indikator & Keterangan \\
\hline Alur & $\begin{array}{l}\text { Alur dalam cerpen ini mengunkan alur campuran (maju-mundur). Hal } \\
\text { tersebut dapat terlihat dari cerita yang dikisahkan oleh tokoh } \\
\text { Ruminisan kepada Bayusan di dalam sebuah apartemen miliknya. } \\
\text { Ingatan yang dilukiskan oleh tokoh Ruminsan ini membuat situasi } \\
\text { dalam cerita sangat menarik. }\end{array}$ \\
\hline Tokoh dan Penokohan & $\begin{array}{l}\text { Tokoh berdasarkan peran penting adalah tokoh utama dan tambahan. } \\
\text { Tokoh utama adalah Taizan, Bayu, Yoshida, Ruminisan dan Saika } \\
\text { Chan. Tokoh berdasarkan fungsi terbagi tokoh protagonis dan } \\
\text { antagonis. Tokoh protagonis adalah Saika Chan dan Ruminisan, } \\
\text { sedangkan tokoh antagonis adalah Yoshida. Tokoh berdasarkan } \\
\text { perwatakan yaitu tokoh bulat dan sederhana. Tokoh bulat yaitu Bayu, } \\
\text { sedangkan tokoh sederhana yaitu Yoshida dan Ruminisan. }\end{array}$ \\
\hline Latar & $\begin{array}{l}\text { Latar adalah tempat, waktu, suasana dan beberapa petunjuk saat } \\
\text { terjadinya cerita berlangsung. Berdasarkan penjelasan dari }\end{array}$ \\
\hline
\end{tabular}

BASASTRA Jurnal Bahasa, Sastra, dan Pengajarannya 


\begin{tabular}{ll}
\hline Nurgiyantoro membagi latar menjadi tiga, yaitu tempat, waktu dan \\
sosial budaya: \\
1. Latar tempat terjadi di luar pintu kamar. \\
2. Latar waktu terjadi ketika kemarin dan Polandia serta menetap di \\
Osaka. \\
3. Latar sosial budaya terlihat suasana bahagia dan perasaan tidak \\
terduga karena kebenaran. Hal ini menyatakan bahwa ada yang \\
menemui Ruminisan ke sebuah apartemen. Ruminisan sangat \\
merasa bahagia, kerena sejak saat itu Ruminisan merasa tidak \\
kesepian dan tidak sendirian lagi. \\
\hline Amanat dalam cerpen adalah sebagai manusia jangan pernah \\
menyimpan dendam terhadap manusia. Hal ini karena sebagai manusia \\
tidak akan pernah tahu yang akan terjadi di masa yang akan datang. \\
\hline Gaya bahasa yang digunakan dalam cerpen menggunakan bahasa \\
Indonesia tidak baku. Bahasa Indonesia biasa digunakan oleh orang \\
Indonesia sebagai alat komunikasi sehari-hari. Penggunaan bahasa \\
Jepang, yang terjadi dalam cerpen adalah kalimat seperti: sumimasen \\
= permisi dan gomenasai= maaf. \\
\hline $\begin{array}{l}\text { Sudut pandang yang dipakai menggunakan sudut pandang persona } \\
\text { ketiga "Dia". Pada sudut ini, narator adalah seseorang yang berada di } \\
\text { luar cerita. Sehingga penyebutan tokoh-tokoh dalam ceritanya pun } \\
\text { menggunakan kata ganti. }\end{array}$ \\
\hline Tema terbagi menjadi dua terdapat tema mayor dan minor. Tema \\
mayor dalam cerpen ini yaitu keluarga. Hubungan keluarga begitu \\
sangat terasa dalam cerpen ini. Sedangkan tema minor dalam cerpen \\
ini adalah kasih sayang seoarang anak kepada ibunya. \\
\hline Tema
\end{tabular}

Nilai toleransi berupa sikap toleransi yang tinggi dan ditunjukkan secara langsung oleh tokoh Ruminisan dan Saikacan. Sementara itu, hubungan erat yang masih dijaga oleh Ruminisan saat bertemu dengan saudara kebangsaan Indonesia yakni Bayusan. Hal tersebut selalu terjadi dalam kehidupan sehari-hari. Ketika dua individu yang memiliki latar belakang kebangsaan yang berbeda. Selanjutnya menjalin hubungan kekeluargaan yang baik. Hal tersebut menjadi indikasi sudah terciptanya sikap toleransi dalam kehidupan.

Untuk cerpen keenam yang berjudul Lebaran di Perantauan (Nurhalimah, 2019), seperti pada Tabel 6 di bawah ini.

Tabel 6. Unsur Intrinsik dalam Cerpen Berjudul Lebaran di Perantauan

\begin{tabular}{ll}
\hline \multicolumn{1}{c}{ Indikator } & \multicolumn{1}{c}{ Keterangan } \\
\hline Alur & $\begin{array}{l}\text { Alur dalam cerpen ini memiliki alur yang maju atau lurus. Cerpen ini } \\
\text { dimulai ketika tokoh Nana bekerja sebagai TKW. Tokoh Nana } \\
\text { memiliki seorang majikan yang sangat baik hati. Pekerjaan tokoh Nana } \\
\text { adalah mengurus seorang nenek yang sudah tua renta. Kebaikan yang } \\
\text { dilakukan oleh Tokoh Nyonya Faang sangat membuat tokoh Nana } \\
\text { bahagia. }\end{array}$ \\
\hline Tokoh dan Penokohan & $\begin{array}{l}\text { Tokoh berdasarkan peran penting terbagi dalam tokoh utama dan } \\
\text { tambahan. Tokoh utama adalah Aku (Nana) dan tokoh tambahan } \\
\text { masih Aku (Nana), Nenek, Mbak Sri dan Nyonya. Tokoh berdasarkan }\end{array}$ \\
\hline
\end{tabular}

BASASTRA Jurnal Bahasa, Sastra, dan Pengajarannya

Volume 9 Nomor 1, April 2021, P-ISSN 2302-6405, E-ISSN 2714-9765 


\begin{tabular}{|c|c|}
\hline & $\begin{array}{l}\text { fungsi terbagi protagonis dan antagonis. Tokoh protagonis adalah Aku } \\
\text { (Nana) dan tokoh antagonis adalah Nyonya. Tokoh berdasarkan } \\
\text { perwatakan yaitu tokoh bulat dan tokoh sederhana. Tokoh bulat yaitu } \\
\text { Aku (Nana), sedangkan tokoh sederhana adalah Nyonya. }\end{array}$ \\
\hline Latar & $\begin{array}{l}\text { Latar adalah tempat, waktu, suasana dan beberapa petunjuk saat } \\
\text { terjadinya cerita berlangsung. Berdasarkan penjelasan dari } \\
\text { Nurgiyantoro membagi latar menjadi tiga, yaitu tempat, waktu dan } \\
\text { sosial budaya: } \\
\text { 1. Latar waktu terjadi ketika mengingat masa lalu dan matahari } \\
\text { belum terlalu panas. } \\
\text { 2. Latar tempat terbagi ketika di taman, penampungan, ruangan kerja } \\
\text { dan kamar. } \\
\text { 3. Latar sosial budaya yang terdapat dalam cerpen ini adalah } \\
\text { kebiasaan salat idulfitri yang biasa dilakukan oleh umat agama } \\
\text { Islam. Selain itu, terdapat beberapa situasi dan suasana yang } \\
\text { menggambarkan keadaan sosial di dalam cerpen. }\end{array}$ \\
\hline Amanat & $\begin{array}{l}\text { Amanat yang terdapat dalam cerpen sebagai manusia harus bisa } \\
\text { menerima perbedaan dan keputusan terhadap keyakinan yang dimiliki } \\
\text { oleh orang lain. Selain itu, memiliki sikap toleransi yang tinggi } \\
\text { terhadap apa pun dan perbedaan yang tidak sesuai dengan apa yang } \\
\text { menjadi pilihan pribadi. Jangan pernah menjadi manusia yang egois } \\
\text { dan selalu ingin dimengerti. Sebab, menghargai perbedaan dan } \\
\text { keyakinan adalah sebuah jalan untuk menciptakan kerukunan dalam } \\
\text { bermasyarakat. }\end{array}$ \\
\hline Bahasa & $\begin{array}{l}\text { Gaya bahasa yang dipakai dalam cerpen menggunakan bahasa } \\
\text { Indonesia tidak baku. Hal tersebut membuat cerpen ini sangat mudah } \\
\text { diterima dan dipahami oleh pembaca. Seperti tempe semangit }=\text { tempe } \\
\text { yang sedikit busuk karena sudah terlalu lama, tandur = buruh } \\
\text { menanam padi dan ngasag = mencari sisa jagung yang sudah diambil } \\
\text { pemiliknya. }\end{array}$ \\
\hline Sudut Pandang & $\begin{array}{l}\text { Sudut pandang yang dipakai menggunakan sudut pandang persona } \\
\text { ketiga "Dia". Pada sudut ini, narator adalah seseorang yang berada di } \\
\text { luar cerita. Sehingga penyebutan tokoh-tokoh dalam ceritanya pun } \\
\text { menggunakan kata ganti. }\end{array}$ \\
\hline Tema & $\begin{array}{l}\text { Tema dalam cerpen terbagi menjadi tema mayor dan minor. Tema } \\
\text { Mayor dalam cerpen mengenai keluarga. Sedangkan tema minor dari } \\
\text { cerpen adalah agama. Hal tersebut dapat dilihat dalam alur ketika } \\
\text { tokoh Nyonya Faang memberikan izin kepada tokoh Nana untuk } \\
\text { melaksanakan ibadah sholat, puasa dan merayakan hari idul fitri. }\end{array}$ \\
\hline
\end{tabular}

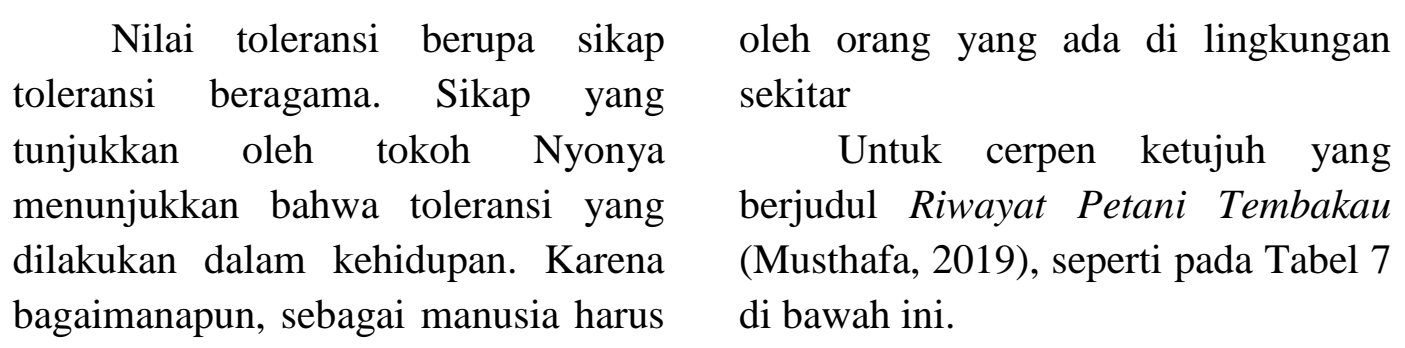

tetap menghargai agama yang dianut

BASASTRA Jurnal Bahasa, Sastra, dan Pengajarannya 
Tabel 7. Unsur Intrinsik dalam Cerpen Berjudul Riwayat Petani Tembakau

\begin{tabular}{|c|c|}
\hline Indikator & Keterangan \\
\hline Alur & $\begin{array}{l}\text { Alur yang diceritakan dalam cerpen ini menggunakan alur maju. Hal } \\
\text { tersebut terlihat dari isi keseluruhan cerpen tidak terdapat ingatan masa } \\
\text { lalu yang muncul dalam ceritan dan tokoh. Cerpen ini mengisahkan } \\
\text { tentang keberhasilan seorang pemuda atas kepercayaannya. }\end{array}$ \\
\hline Tokoh dan Penokohan & $\begin{array}{l}\text { Tokoh dalam cerpen ini yaitu Ahmad, Salim, Nenek, Kakek Markum } \\
\text { dan Kiai Rasyid. }\end{array}$ \\
\hline Latar & $\begin{array}{l}\text { Latar adalah tempat, waktu, suasana dan beberapa petunjuk saat } \\
\text { terjadinya cerita berlangsung. Berdasarkan penjelasan dari } \\
\text { Nurgiyantoro membagi latar menjadi tiga, yaitu tempat, waktu dan } \\
\text { sosial budaya: } \\
\text { 1. Latar tempat saat di emperan rumah, sepulang dari masjid, } \\
\text { tembakau yang mereka lihat, menyusuri rupa-rupa jalan dan } \\
\text { akhirnya sampai di Tegal. } \\
\text { 2. Latar waktu terjadi saat pagi, di tahun itu, } 35 \text { hari, berusia } 70 \text { hari, } \\
\text { berusia } 5 \text { bulan dan minggu-minggu berlalu. } \\
\text { 3. Latar sosial budaya suasana yang terjadi dalam cerpen yakni } \\
\text { suasana panik. }\end{array}$ \\
\hline Amanat & $\begin{array}{l}\text { Amanat yang adalah jika mendapatkan rezeki dari Allah Swt., sebagai } \\
\text { manusia jangan pernah lupa untuk bersedekah. Hal ini dikarenakan di } \\
\text { dalam rezeki yang dimiliki ada hak orang lain di dalamnya. }\end{array}$ \\
\hline Bahasa & $\begin{array}{l}\text { Gaya bahasa yang diceritakan dalam cerpen menggunakan bahasa } \\
\text { Indonesia tidak baku yang biasa digunakan dalam berkomunikasi } \\
\text { sehari-hari. Selain itu dalam cerpen ini tidak ditemukan kosa kata yang } \\
\text { sulit dipahami. Sehingga pembaca dengan mudah langsung memahmi } \\
\text { isi cerpen tersebut. }\end{array}$ \\
\hline Sudut Pandang & $\begin{array}{l}\text { Sudut pandang yang dipakai menggunakan sudut pandang persona } \\
\text { ketiga "Dia". Pada sudut ini, narator adalah seseorang yang berada di } \\
\text { luar cerita. Sehingga penyebutan tokoh-tokoh dalam ceritanya pun } \\
\text { menggunakan kata ganti. }\end{array}$ \\
\hline Tema & $\begin{array}{l}\text { Tema dalam cerpen terbagi menjadi tema mayor dan minor. Tema } \\
\text { mayor dalam cerpen adalahh mengangkat tema sosial yang biasa } \\
\text { terjadi dalam kehidupan sehari-hari. Sedangkan tema minor adalah } \\
\text { tema yang hanya menjadi bagian kecil dari keseluruhan isi cerita. }\end{array}$ \\
\hline
\end{tabular}

Nilai toleransi berupa tokoh menyebutkan alasan mengapa menolak Salim memiliki karakter yang sopan, sangat menyayangi keluarga dan patah semangat. Hal tersebut dapat dilihat ketika Salim dihadapkan pada pilihan yang ditawarkan oleh Ahmad untuk bekerja di luar kota. Namun, Salim memberikan sikap penolakan kepada Ahmad dengan cara yang baik dan tawaran Ahmad sehingga Ahmad tidak merasa tersinggung dengan penolakan yang diberikan oleh Salim.

Untuk cerpen kedelapan yang berjudul Bukan Untukmu Kujemput Rindu (Kelana, 2019), seperti pada Tabel 8 di bawah ini. 
Tabel 8. Unsur Intrinsik dalam Cerpen Berjudul Bukan Untukmu Kujemput Rindu

\begin{tabular}{|c|c|}
\hline Indikator & Keterangan \\
\hline Alur & $\begin{array}{l}\text { Alur yang terjadi dalam cerpen menggunakan alur campuran yaitu } \\
\text { maju dan mundur. Alur ini sangat kompleks terjadi dalam cerpen. } \\
\text { Sebab banyak sekali ingatan masa lalu yang dimunculkan pada tokoh } \\
\text { Saiful untuk mengingat masa lalunya yang sangat pedih. }\end{array}$ \\
\hline Tokoh dan Penokohan & $\begin{array}{l}\text { Tokoh berdasarkan peran penting yakni ada dua tokoh utama dan } \\
\text { tokoh tambahan. Tokoh utama adalah Aku (Saiful) dan tokoh } \\
\text { tambahan adalah Ibu. Tokoh berdasarkan fungsi yaitu tokoh } \\
\text { protagonis dan tokoh anatagonis. Tokoh protagonis adalah Marisa dan } \\
\text { tokoh antagonis adalah Aku (Saiful). Tokoh berdasarkan perwatakan } \\
\text { terbagi tokoh bulat dan sederhana. Tokoh bulat adalah Marisa dan } \\
\text { tokoh sederhana adalah Aku (Saiful). }\end{array}$ \\
\hline Latar & $\begin{array}{l}\text { Latar adalah tempat, waktu, suasana dan beberapa petunjuk saat } \\
\text { terjadinya cerita berlangsung. Berdasarkan penjelasan dari } \\
\text { Nurgiyantoro membagi latar menjadi tiga, yaitu tempat, waktu dan } \\
\text { sosial budaya: } \\
\text { 1. Latar tempat saat di Rumah Sakit, Kalimantam, Cluster Malaka } \\
\text { dan Perumahan Telaga Golf Sawangan. } \\
\text { 2. Latar waktu terjadi ketika pukul } 04.30,05.45 \text {, hari Ahad, besok } \\
\text { pagi, lima belas tahun, saat lebaran dan } 07.00 \text {. } \\
\text { 3. Latar sosial budaya sebenarnya di dalam cerpen ini tidak } \\
\text { ditemukan latar sosial budaya. Namun, cerpen ini menunjukkan } \\
\text { beberapa situasi dan kondisi sosial dan suasana yang mampu } \\
\text { membuat pembaca merasa terbawa suasana. Suasana yang muncul } \\
\text { dalam cerpen ini berbeda-beda yakni terdapat suasana sedih, } \\
\text { bahagia dan penyesalan. }\end{array}$ \\
\hline Amanat & $\begin{array}{l}\text { Amanat yang disampaikan dalam cerpen ini, yakni bahwa sebagai } \\
\text { manusia harus bisa menghargai perbedaan yang dimiliki oleh sesama } \\
\text { manusia dan janganlah menjadi orang yang pendendam. }\end{array}$ \\
\hline Bahasa & $\begin{array}{l}\text { Gaya bahasa yang dipakai dalam cerpen ini menggunakan bahasa } \\
\text { Indonesia sehari-hari yang tidak baku. Sehingga mudah dibaca dan } \\
\text { dipahami oleh pembaca. Selain itu dalam cerpen ini tidak terdapat kosa } \\
\text { kata asing ataupun kosa kata daerah yang sukar dipahami. }\end{array}$ \\
\hline Sudut Pandang & $\begin{array}{l}\text { Sudut pandang yang dipakai menggunakan sudut pandang persona } \\
\text { ketiga: "Dia". Pada sudut ini, narator adalah seseorang yang berada di } \\
\text { luar cerita. Sehingga penyebutan tokoh-tokoh dalam ceritanya pun } \\
\text { menggunakan kata ganti. }\end{array}$ \\
\hline Tema & $\begin{array}{l}\text { Tema dalam cerpen terbagi menjadi tema mayor dan minor. Tema } \\
\text { mayor diangkat dalam cerpen ini tentang kasih sayang. Kasih sayang } \\
\text { dalam cerpen ini ditunjukkan secara langsung oleh tokoh yang } \\
\text { bernama Saiful, Ibu dan Marisa. Sedangkan tema minor hanya menjadi } \\
\text { bagian kecil dari keseluruhan isi cerita. }\end{array}$ \\
\hline
\end{tabular}

Nilai toleransi yang terjadi dalam cerpen tersebut, yakni pada saat Marissa memberikan sepucuk surat. Surat tersebut ditulis secara langsung oleh almarhumah ibundanya ketika masih hidup. Marissa memberikan surat itu kepada Saiful di tempat pemakaman ibunya.

Untuk cerpen kesembilan yang berjudul Shalawat Cinta dari Venesia (Kelana, 2019), seperti pada Tabel 9 di bawah ini. 
Tabel 9. Unsur Intrinsik dalam Cerpen Berjudul Shalawat Cinta dari Venesia

\begin{tabular}{|c|c|}
\hline Indikator & Keterangan \\
\hline Alur & Alur yang terjadi menggunakan alur campuran. \\
\hline Tokoh dan Penokohan & $\begin{array}{l}\text { Tokoh berdasarkan peran penting terbagi menjadi tokoh utama dan } \\
\text { tokoh tambahan. Tokoh berdasarkan fungsi berdasarkan tokoh } \\
\text { protagonis dan okoh anatagonis. Tokoh berdasarkan perwatakan yaitu } \\
\text { tokoh bulat dan tokoh sederhana. Tokoh-tokohnya bernama Habibah, } \\
\text { Fadli, Melati dan Irham. }\end{array}$ \\
\hline Latar & $\begin{array}{l}\text { Latar adalah tempat, waktu, suasana dan beberapa petunjuk saat } \\
\text { terjadinya cerita berlangsung. Berdasarkan penjelasan dari } \\
\text { Nurgiyantoro membagi latar menjadi tiga, yaitu tempat, waktu dan } \\
\text { sosial budaya: } \\
\text { 1. Latar waktu ketika, } 10 \text { hari, } 20 \text { menit, hari terakhir, hari keempat, } \\
\text { hari pertama, dua bulan lalu, tiga tahun lalu, dua tahun sesudah } \\
\text { pernikahan, lulus SMA kuliah di ITB, setahun kemudian dan tepat } \\
\text { seminggu yang lalu. } \\
\text { 2. Latar tempat saat berada di pesawat Qatar Airlines rute Roma- } \\
\text { Jakarta dan menaiki tangga pelaminan. } \\
\text { 3. Latar sosial budaya yang terdapat dalam cerpen adalah reuni. } \\
\text { Selain itu, keadaan sosial yang dialami oleh tokoh Habibah adalah } \\
\text { menutup diri dan menghindari beberapa pertemuan yang ada } \\
\text { kaitannya dengan tokoh Fadli. Hal tersebut membuat komunikasi } \\
\text { sosial Habibah terganggu dan terputus kongsi dengan teman- } \\
\text { temannya. }\end{array}$ \\
\hline Amanat & $\begin{array}{l}\text { Amanat dalam cerpen ini sebagai manusia harus selalu memiliki } \\
\text { prasangka baik terhadap takdir yang telah Allah rencanakan. Jika } \\
\text { menemukan rasa sakit ataupun kesusahan, percayalah kelak Allah } \\
\text { akan berikan beribu pintu kemudahan. }\end{array}$ \\
\hline Bahasa & $\begin{array}{l}\text { Gaya bahasa yang dipakai menggunakan bahasa Indonesia tidak baku. } \\
\text { Bahasa Indonesia tidak baku ini biasa digunakan dalam percakapan } \\
\text { sehari-hari. Oleh karena itu, pembaca dapat dengan mudah memahami } \\
\text { isi cerita dari cerpen. }\end{array}$ \\
\hline Sudut Pandang & $\begin{array}{l}\text { Sudut pandang yang dipakai oleh penulis dalam menganalisis cerpen } \\
\text { ini adalah sudut pandang orang ketiga. }\end{array}$ \\
\hline Tema & $\begin{array}{l}\text { Tema dalam cerpen terbagi menjadi tema mayor dan minor. Tema } \\
\text { mayor dalam cerpen tentang kesabaran dalam menantikan cinta sejati. } \\
\text { Cerita yang sangat memotivasi pembaca untuk bersikap sabar untuk } \\
\text { menerima semua tentang keputusan, perbedaan pendapat dan sudut } \\
\text { pandang dalam menilai sesuatu. Sedangkan tema minor hanya menjadi } \\
\text { bagian kecil dari keseluruhan isi cerita. }\end{array}$ \\
\hline
\end{tabular}

Nilai toleransi berupa sikap tidak memiliki perasaan dendam dan toleransi yang ditunjukkan oleh niat tidak baik terhadap keputusan Habibah biasa terjadi dalam kehidupan sehari-hari. Sikap menerima takdir yang telah terjadi dapat dilewati oleh Habibah dengan penuh rasa sabar dan tenang. Selain itu Habibah sama sekali

Fadil untuk menikahi Melati.

Untuk cerpen kesepuluh yang berjudul Mimpi dan Takdir (Sabathani, 2019), seperti pada Tabel 10 di bawah ini. 
Tabel 10. Unsur Intrinsik dalam Cerpen Berjudul Mimpi dan Takdir

\begin{tabular}{|c|c|}
\hline Indikator & Keterangan \\
\hline Alur & $\begin{array}{l}\text { Alur yang terjadi di dalam cerpen menggunakan alur campuran. Hal } \\
\text { tersebut dapat terlihat saat penulis menceritakan kisah demi kisah } \\
\text { secara bertahap sesuai dengan alur cerita. Terdapat fase ingatan yang } \\
\text { dimunculkan pada tokoh utama. Meski alur flashback tersebut } \\
\text { dihadirkan dalam cerita ini, hal tersebut membuat cerita memiliki alur } \\
\text { maju dan mundur. }\end{array}$ \\
\hline Tokoh dan Penokohan & $\begin{array}{l}\text { Tokoh berdasarkan peran penting, yaitu tokoh utama dan tambahan. } \\
\text { Tokoh utama adalah Fatur dan tokoh tamabahan Fahmi, Ibu, Bapak } \\
\text { dan Wahid. Tokoh berdasarkan fungsi yaitu protagonis dan antagonis. } \\
\text { Tokoh protagonis adalah Wahid dan Fatur, sedangkan tokoh antagonis } \\
\text { adalah Bapak. Tokoh berdasarkan perwatakan yaitu bulat dan } \\
\text { sederhana. Tokoh bulat adalah Fatur, sedangkan sederhana adalah } \\
\text { Wahid. }\end{array}$ \\
\hline Latar & $\begin{array}{l}\text { Latar adalah tempat, waktu, suasana dan beberapa petunjuk saat } \\
\text { terjadinya cerita berlangsung. Berdasarkan penjelasan dari } \\
\text { Nurgiyantoro membagi latar menjadi tiga, yaitu tempat, waktu dan } \\
\text { sosial budaya: } \\
\text { 1. Latar waktu ketika pada sore hari dan pernah suatu hari. } \\
\text { 2. Latar tempat terjadi di rumahku di Palu Sulawesi Tenngah, } \\
\text { Jakarta, kantor dan kampung halaman. } \\
\text { 3. Latar sosial budaya terlihat suasana menegangkan yang dirasakan } \\
\text { oleh tokoh yang bernama Fatur. Fatur merasakan tegang saat } \\
\text { dirinya bermimpi hal-hal yang sangat menegangkan dan } \\
\text { menakutkan. }\end{array}$ \\
\hline Amanat & $\begin{array}{l}\text { Amanat yang terkandung di dalamnya untuk pembaca berupa sebagai } \\
\text { manusia harus menghargai, menghormati dan menerima perbedaan } \\
\text { keyakinan antara diri sendiri dengan orang lain. Selain itu juga, } \\
\text { sebagai manusia jangan pernah memaksakan kehendak dan harus tetap } \\
\text { rendah hati serta bersikap toleran kepada sesama manusia. }\end{array}$ \\
\hline Bahasa & $\begin{array}{l}\text { Gaya bahasa yang dipakai dalam cerpen menggunakan bahasa } \\
\text { Indonesia sehari-hari. Sehingga, cerita pendek ini, sangat mudah di } \\
\text { mengerti, dipahami dan dinikmati oleh pembaca. }\end{array}$ \\
\hline Sudut Pandang & $\begin{array}{l}\text { Sudut pandang yang dipakai menggunakan sudut pandang persona } \\
\text { ketiga: "Dia". Pada sudut persona ketiga ini, narator adalah seseorang } \\
\text { yang berada di luar cerita. Sehingga penyebutan tokoh-tokoh dalam } \\
\text { ceritanya pun menggunakan kata ganti. }\end{array}$ \\
\hline Tema & $\begin{array}{l}\text { Tema dalam cerpen terbagi tema mayor dan minor. Tema mayor yang } \\
\text { diangkat dalam cerpen tentang kepercayaan dalam keluarga. } \\
\text { Sedangkan tema minor hanya menjadi bagian kecil dari keseluruhan } \\
\text { isi cerita. }\end{array}$ \\
\hline
\end{tabular}

Nilai toleransi yang menonjol dalam cerpen ini adalah pada saat Fatur mengetahui bahwa ternyata bapak, ibu dan adiknya tidak sependapat. Perihal dengan yang selama ini dia yakini tentang mimpi-mimpinya akan menjadi kenyataan. Sebenarnya tokoh Fatur sangat merasa kesal, namun tetap menghargai kepercayaan yang dimiliki oleh keluarganya. Bahkan tokoh Bapak dalam cerpen ini memberikan ungkapan bahwa pada dasarnya, sebagai umat muslim yang menganut agama Islam harus selalu percaya pada

BASASTRA Jurnal Bahasa, Sastra, dan Pengajarannya 
ketentuan yang sudah Allah berikan sejak masih berada dalam kandungan. Selain itu, jangan pernah percaya kepada hal-hal lain selain percaya kepada Allah.

Berdasarkan hasil analisis, penulis mendapatkan hasil untuk pemanfaatan 10 cerpen Republika Daring Tahun 2019 sebagai relevansi materi ajar sastra di SMA. Penulis memilih 10 cerpen sebagai materi ajar di dalam handout. Karena penulis menyadari bahwa handout adalah materi ajar cetak yang dapat dengan mudah digunakan oleh pengajar dalam kegiatan belajar mengajar. Oleh karena itu, penulis telah membuat handout mata pelajaran Bahasa Indonesia bagian materi cerpen untuk kompetensi dasar 3.8, 4.8, 3.9, 4.9 dalam kurikulum 2013. Khususnya pada materi cerpen bagian nilai toleransi yang terdapat dalam sebuah karya sastra cerpen.

Handout dibuat memiliki tujuan yaitu untuk para guru Bahasa Indonesia dalam melakukan kegiatan belajar mengajar dengan mudah dan praktis. Selain itu handout digunakan oleh siswa/i sebagai sumber materi ajar yang akan dipelajari. Hal ini terkait dengan materi yang akan dibahas. Dalam penulisan kali ini membuat handout sebagai bahan relevansi ajar sastra:

(1) Kompetensi Dasar (KD) 3.8 dan 4.8, mencakup beberapa materi yang siap diberikan kepada siswa/i di sekolah. Siswa/i akan mendapatkan materi pelajaran berupa pengertian cerpen, unsurunsur intrinsik cerpen dan nilainilai pendidikan karakter dalam cerpen.

(2) Kompetensi Dasar (KD) 3.9 dan 4.9, mencakup unsur-unsur pembangun dalam cerpen dan cara menelaah unsur pembangun dalam cerpen

Kemudian setelah diberikan materi berupa KD 3.8, 4.8, 3.9 dan 4.9 di atas. Maka untuk mengetahui parameter siswa/i telah memahami materi yang diberikan. Dibuatkan soal latihan sederhana dari $\mathrm{KD}$ di atas. Beberapa pertanyaan yang diajukan:

(1) Sebutkan nilai toleransi apa saja yang terdapat dalam cerpen kalian baca.

(2) Sebutkan unsur intrinsik cerpen yang sudah kalian baca.

\section{SIMPULAN}

Tema dalam penelitian ini adalah tema mayor dan tema minor. Tema yang terdapat dalam penulisan ini meliputi, keluargaan, agama, kasih sayang, kesabaran, kepercayaan. Alur dalam penelitian ini, terdapat tiga yakni: alur lurus, sorot balik dan campuran. Hampir sebagian besar cerpen yang dianalisis menggunakan alur campuran (alur maju-mundur). Latar dalam cerpen ini adalah di taman, rumah, balkon rumah, airport, masjid, jalan, Banjarmasin, Depok, Jepang dan Taiwan. Tokoh dan penokohan terdapat 98 tokoh gabungan. Setiap masing-masing tokoh memiliki karakteristik yang berbeda-beda. Sudut 
pandang yang dipakai adalah menggunakan orang ketiga serba tahu. Bahasa yang digunakan rata-rata menggunakan bahasa sehari-hari. adalah sebagai makhluk sosial harus mampu menerapkan sikap toleransi dalam kehidupan sehari-hari di masyarakat. Nilai toleransi yang terkandung adalah saling menghargai perbedaan pendapat, agama, kepercayaan, sudut pandang orang lain yang biasa terjadi di dalam kehidupan masyarakat. Selain itu, hasil dari penelitian ini membuat handout sebagai materi ajar sastra. Handout bertujuan untuk memudahkan para guru dalam menjelaskan materi terhadap murid. Hal ini akan menjadi parameter untuk guru seberapa besar murid sudah memahami materi yang disediakan.

Maka rekomendasi yang dapat diberikan yaitu hasil penelitian dapat dijadikan sebagai materi ajar sastra di SMA. Selain itu, sebagai bahan referensi penelitian sastra khususnya analisis nilai toleransi dalam cerpen Koran Republika Daring 2019. Sementara untuk penelitian selanjutnya menganalisis kembali beberapa cerpen dari sumber lain. Dengan mempertimbangkan (1) unsur intrinsik, (2) nilai toleransi, dan (3) relevansi sebagai bahan ajar sastra. Hal ini bertujuan guna penelitian selanjutnya yang lebih kompleks dalam menganalisis cerpen
Namun, ada juga yang menggunakan bahasa asing seperti bahasa Jepang. Pesan moral yang dapat disimpulkan

\section{REFERENSI}

Abdullah, R. D. (2019). Lelaki Pengurus Orang Mati. Jakarta: Republika.

Anderson, I. \& Putri, N. P. (2017). Implementasi Nilai Toleransi dalam Pembelajaran Tematik di Sekolah Dasar. Jurnal Gentala Pendidikan Dasar, 2 (2), 275291.

Anggraini, N. (2020.) Kemampuan Menentukan Unsur Instrinsik Cerpen "Merdeka" Karya Putu Wijaya pada Siswa Kelas VIII SMP Kartika II-2 Bandar Lampung. Ksatra: Jurnal Kajian Bahasa dan Sastra, 2 (1), 63-68.

Emzir \& Rohman. (2016). Teori dan Pengajaran Sastra. Jakarta: PT Raja Grafindo Persada.

Hartini, J. (2019). Kalam Ilahi di Balik Jeruji Besi. Jakarta: Republika.

Heri, E. (2019). Menggagas Sebuah Cerpen. Semarang: Alprin.

Ilham, M. \& Wijati, I. A. (2018). Nilai Pendidikan Karakter Demokratis dan Toleransi dalam Novel Karya Habiburrahman El Shirazy dan Relevansinya dengan Pembelajaran Sastra. Kode: Jurnal Bahasa, 7 (4), 1-10.

Intisari. (2020). Tragedi Sampit. Diakses daring pada 8 Juni 2020 dari https://www.grid.id.

Irwan, M. (2011). Berislam Secara Toleran Teologi Kerukunan Umat Beragama. Bandung: PT Mizan. 
Juanda, J. (2018). Eksplorasi Nilai Pendidikan Lingkungan Cerpen Daring Republika: Kajian Ekokritik. Jurnal Sosial Humaniora (JSH), 9 (2), 67-81.

Juliawanti, L. (2018). Penyerangan Klenteng. Diakses daring pada 11 Februari 2020 dari https://www.idntimes.com

Kahfi, M. R. (2018). Nilai Toleransi dalam Novel Ayat-Ayat Cinta 2 Karya Habiburrahman ElShirazy. Locana: Jurnal Akhir Mahasiswa PS PBSI FKIP ULM, 1 (1), 18-26.

Kelana, I. (2019). Bukan Untukmu Kujemput Rindu. Jakarta: Republika. (2019). Hati Sang Pemilik

Kucing. Jakarta: Republika. . (2019). Shalawat Cinta dari

Venesia. Jakarta: Republika.

Limbong, J. L. (2016). Kemampuan

Menentukan Unsur Intrinsik

Cerpen Melalui Model

Pembelajaran Inkuiri Siswa

Kelas VIII SMP Negeri 10 Kota

Palopo. Jurnal Onoma:

Pendidikan, Bahasa dan Sastra, 2 (1), 12-26.

Maryanti, D., Sujiana, R. \& Wikanengsih. (2018).

Menganalisis Unsur Intrinsik Cerpen Katastropa Karya Han Gagas sebagai Upaya Menyediakan Bahan Ajar Menulis Teks Cerpen. Parole: Jurnal Pendidikan Bahasa dan Sastra Indonesia, 1 (5), 787-792. Musthafa, A. (2019). Riwayat Petani Tembakau. Jakarta: Republika.

Muzakir, 2020. Penyerangan Mushola.

Diakses daring pada 31 September 2020 dari https://www.bbc.com.
Nurhalimah, E. (2019). Lebaran di Perantauan. Jakarta: Republika. (2019). Pelangi di Kota Changhua. Jakarta: Republika.

Nurjaya, H. K., Supendi, D. A. \& Firdaus, A. (2019). Unsur Intrinsik dan Ekstrinsik Kumpulan Cerpen Senyum Karyamin Karya Ahmad Tohari sebagai Bahan Ajar. Imajeri: Jurnal Pendidikan Bahasa dan Sastra Indonesia, 1 (2), 70-90.

Rantesalu, M. B. \& Iswanto.(2020). Toleransi Berdasarkan Cerita Rakyat Tallu To Sala' di Toraja. BIA': Jurnal Teologi dan Pendidikan Kristen Kontekstual, 1 (1), 13-25.

Sabathani, R. (2019). Mimpi dan Takdir. Jakarta: Republika.

Sapdiani, R., Maesaroh, I., Pirmansyah, P. \& Firmansyah, D. (2018). Analisis Struktural dan Nilai Moral dalam Cerpen "Kembang Gunung Kapur" Karya Hasta Indriyana. Parole: Jurnal Pendidikan Bahasa dan Sastra Indonesia, 1 (2), 101-114.

Subekti, D. D., Sutarjo, A. \& Wardana, D. (2016). Analisis Unsur Intrinsik dalam Antologi Cerpen Aku Sayang Saudaraku Karya Albye Syafie sebagai Bahan Pembelajaran Menulis Karangan Narasi bagi Siswa Kelas V di Sekolah Dasar. Jurnal Kalimaya, 4 (2), 1-9.

Sugiyono. (2017). Metode Penelitian Kuantitatif, Kualitatif dan $R \& D$. Bandung: Alfabeta.

Suhardi \& Thahirah, A. (2018). Nilai Pendidikan Karakter pada Cerpen Waskat Karya Warisan Hadi. Jurnal Pendidikan Bahasa dan Sastra, 18 (1), 114-122. 
Sukma, A., Andayani \& Mujiyanto, Y., (2019). Kajian Sosiologi Sastra dan Nilai Toleransi pada Novel Kambing dan Hujan Karya Mahfud Ikhwan serta Relevansinya dengan Materi Ajar Apresiasi Sastra di SMA Kelas XII. Basastra: Jurnal Penelitian Bahasa, Sastra Indonesia dan Pengajarannya, 6 (2), 40-52.

Suryadi, J., Azis, M. M. A. \& Utama, S. A. (2018). Refleksi Toleransi dalam Novel "Hujan" Karya Tere Liye. Seminar Nasional Bahasa dan Sastra, Malang.

Suyadi, R. \& Nuryatin, A. (2017). Nilai Pendidikan dalam Antologi Cerpen Senyum Karyamin Karya Ahmad Tohari. Seloka: Jurnal Pendidikan Bahasa dan Sastra Indonesia, 6 (3), 314-322.

Tantri, A. A. S. (2017). Nilai-Nilai Pendidikan Karakter dalam Novel Tantri (Perempuan yang Bercerita) Karya Cok Sawitri sebagai Alternatif Pembelajaran Sastra di Sekolah Dasar. The 1st Education and Language International Conference Proceedings Center for International Language Development of Unissula. Universitas Sultan Agung Semarang.
Utomo, R. O., Hasanah, M. \& Maryaeni. (2020). Telaah Nilai Toleransi Sosial dalam Novel Karya Ahmad Tohari. Jurnal Pendidikan: Teori, Penelitian, dan Pengembangan, 5 (6), 792802.

Vardani, E. N. A. (2018). Penanaman Nilai-Nilai Karakter Islam dalam Cerpen Aku Ingin Emak Masuk Surga Karya Maiyade Laila Yane. Belajar Bahasa: Jurnal Ilmiah Program Studi Pendidikan Bahasa \& Sastra Indonesia, 3 (1), 23-37.

Wahyudi. (2019). Nilai Toleransi Beragama dalam Tradisi Genduren Masyarakat Jawa Transmigran. Jurnal Studi Agama dan Masyarakat, 55 (2), 133-139.

Widiyanto, D. (2017). Penanaman Nilai Toleransi dan Keragaman Melalui Strategi Pembelajaran Tematik Storybook pada Mata Pelajaran PPKn di Sekolah Dasar. Jurnal Pendidikan Kewarganegaraan, 8 (2), 28-36.

Zakaria, A. (2019). Setagaya Aku Ingin Pulang. Jakarta: Republika. 